\title{
A Vector Autoregressive Market Model for IT Sector Stocks in India
}

\author{
Mihir Dash \\ School of Business, Alliance University \\ India \\ Rita S. \\ Department of Statistics, Periyar University \\ India
}

Received: March 10, $2021 \quad$ Accepted: June 1, $2021 \quad$ Published: June 1, 2021

doi:10.5296/ajfa.v13i1.18589 URL: https://doi.org/10.5296/ajfa.v13i1.18589

\begin{abstract}
This study proposes a vector autoregressive form for the market model and tests its significance against the market model for information technology (IT) sector stocks in the Indian stock market. The analysis was performed for a sample of nineteen IT sector stocks listed on the National Stock Exchange of India, of which nine stocks were large-cap, six were mid-cap, and four were small-cap. The study period considered was Jan. 1, 2018 - Dec. 31, 2018.

The key contribution of the study was the finding that the vector autoregressive model is a better model of stock returns than the market model for IT sector stocks. Thus, IT sector stocks seem to react more to market movements from the previous day than on the day itself. The implication for asset pricing modelling is that systematic risk may be further decomposed into a component corresponding to sensitivity to market movements on the day and a component corresponding to sensitivity to market movements on the previous day. The asset pricing model would be extended to include market risk premia for both of these components of systemic risk.
\end{abstract}

Keywords: market model, vector autoregressive model, IT sector, asset pricing modelling, systematic risk. 


\section{Introduction}

The market model (also called the single-index model) is a framework which represents the inter-relationship between all stocks through the market portfolio (Sharpe, 1963). It asserts that stock returns are linearly related with market returns, specifically,

$$
r_{t}=\alpha+\beta r_{M, t}
$$

where $\alpha$ is the expected return of the stock when market return is zero, and $\beta$ is the sensitivity of stock returns to changes in market returns. The model also yields a decomposition of the total risk/volatility of stock returns into a systematic component (related with market risk) and an unsystematic component (risk that is specific to the stock). Subsequently, the parameter $\beta$ plays a pivotal role in the Capital Asset Pricing Model (CAPM), which relates the expected returns of the stock with its systematic risk.

The market model is very widely used in financial research, for evaluating and comparing stock/portfolio performance, for estimating systematic risk and cost of capital in capital budgeting, for computing abnormal returns in event studies (e.g. Brown and Warner, 1980), and for testing asset pricing models (Fama and MacBeth, 1973; Gibbons, 1988).

Several studies have identified certain econometric limitations with the market model, particularly heteroskedasticity. McDonald and Lee (1988) proposed a generalised functional form for the market model using Box-Cox transformations in order to stabilise variance and reduce heteroskedasticity. Coutts et al (1997) found significant parameter instability in the market model, which they suggested was affected considerably by non-firm-specific events. Mills (1995) suggested that the market model should be estimated only after examining cointegration and/or short-run dynamics of the relationship between the stock price and the market index. Fama and Ross (1976) proposed the Arbitrage Pricing Theory, which generalised the CAPM to include multiple macro-economic factors in the market model. French (1996) extended the CAPM by including the size and book-to-market effects. Carhart (1997) suggested a further extension of the Fama-French three-factor model including the momentum factor.

Another direction along which the CAPM was extended was that of autocorrelation. Jegadeesh and Titman (1993) explained medium-term autocorrelation in stock returns using the momentum effect. Chan (1993) suggested that cross-autocorrelations in stock returns may be explained through nonsynchronous trading and that, further, cross-autocorrelation coefficients of stock returns are significantly higher under large market movements than under small market movements. Soufian (2001) suggested that, before analysing factor models, it is essential to identify the process that generating the stock returns and macro-economic series and that vector autoregressive models may be used for this purpose. Dash $(2014,2017)$ has used vector autoregressive models to test for Granger causality between stock returns and market returns.

The present study proposes a vector autoregressive form for the market model and tests its significance against the market model for information technology (IT) sector stocks in the Indian stock market. 


\section{Al Macrothink}

Asian Journal of Finance \& Accounting

ISSN 1946-052X

2021, Vol. 13, No. 1

\section{Data \& Methodology}

The objective of the study is to examine vector autoregressive extensions of the market model for IT sector stocks in the Indian stock market.

The sample stocks considered for the study are listed in Table 1 below. The study period considered was Jan. 1, 2018 - Dec. 31, 2018. The data was collected from the National Stock Exchange of India (www.nseindia.com). The NSE index Nifty 50 was considered as a proxy for the market portfolio. The risk-free rate was taken to be $6.33 \%$ p.a. based on average MIBOR for the study period.

Table 1. Sample stocks considered for the study

\begin{tabular}{|l|l|}
\hline Large-cap & Mid-cap \\
\hline Tata Consultancy Services & Persistent Systems \\
\hline Infosys Technologies & Firstsource Solutions \\
\hline Wipro Technologies & Cyient \\
\hline HCL Technologies & Hexaware Technologies \\
\hline Tech Mahindra & Sonata Software \\
\hline Larsen \& Tourbo Infotech & Zenstar Technologies \\
\hline MindTree & \\
\hline Mphasis & Small-cap \\
\hline Oracle Financials Services Software & Eclerx Services \\
\hline & NIIT Technologies \\
\hline & Nucleus Software Exports \\
\hline & Mastek \\
\hline
\end{tabular}

The daily returns of the sample stocks and of the Nifty 50 index were computed as the percentage change in daily closing prices, adjusting for dividends and stock splits/bonus share issues, if any. The Kwiatkowski-Phillips-Schmidt-Shin (KPSS) test was used to test the stationarity of the series.

The market model was estimated for each of the sample stocks using the regression model:

$r_{t}=\alpha+\beta r_{M, t}+\varepsilon_{t}$

As an alternative, the study proposes a vector autoregressive market model of the form:

$r_{t}=\alpha+\varphi_{1} r_{t-1}+\cdots+\varphi_{p} r_{t-p}+\beta r_{M, t}+\beta_{1} r_{M, t-1}+\cdots+\beta_{q} r_{M, t-q}+\varepsilon_{t}$

where the lag structures $\mathrm{p}$ and $\mathrm{q}$ are determined by minimising the Akaike Information Criterion (AIC).

The significance of the vector autoregressive model over the market model is tested using the nested F-test. 


\section{Macrothink}

Asian Journal of Finance \& Accounting

ISSN 1946-052X

2021, Vol. 13, No. 1

\section{Analysis \& Findings}

The descriptive statistics of the sample stock returns are presented in Tables $2 a, 2 b$, and $2 c$ below.

Table 2a. Descriptive statistics of daily returns - large cap stocks

\begin{tabular}{|c|c|c|c|c|c|c|c|c|c|}
\hline & $T C S$ & $\begin{array}{c}\text { Infosys } \\
\text { Tech }\end{array}$ & $\begin{array}{c}\text { Wipro } \\
\text { Tech }\end{array}$ & $\begin{array}{l}H C L \\
T e c h\end{array}$ & $\begin{array}{c}\text { Tech } \\
\text { Mahindra }\end{array}$ & $\begin{array}{c}L \& T \\
\text { Infotech }\end{array}$ & MindTree & Mphasis & $\begin{array}{c}\text { Oracle } \\
\text { Fin } \\
\text { Serv }\end{array}$ \\
\hline Mean & $0.17 \%$ & $0.14 \%$ & $0.07 \%$ & $0.08 \%$ & $0.18 \%$ & $0.19 \%$ & $0.20 \%$ & $0.13 \%$ & $-0.02 \%$ \\
\hline Std Dev & $1.63 \%$ & $1.48 \%$ & $1.40 \%$ & $1.77 \%$ & $1.94 \%$ & $2.50 \%$ & $2.62 \%$ & $2.33 \%$ & $1.64 \%$ \\
\hline Sharpe & 0.0898 & 0.0738 & 0.0302 & 0.0317 & 0.0795 & 0.0669 & 0.0673 & 0.0465 & -0.0288 \\
\hline Skewness & 0.2911 & -0.1829 & -0.0830 & -0.7078 & 0.0314 & 0.6378 & -0.8777 & 0.3736 & 0.1638 \\
\hline Max. & $6.41 \%$ & $4.21 \%$ & $5.24 \%$ & $4.93 \%$ & $8.23 \%$ & $11.32 \%$ & $9.18 \%$ & $9.12 \%$ & $5.42 \%$ \\
\hline Min. & $-5.57 \%$ & $-4.66 \%$ & $-4.15 \%$ & $-7.77 \%$ & $-7.26 \%$ & $-7.68 \%$ & $-18.36 \%$ & $-6.17 \%$ & $-5.25 \%$ \\
\hline
\end{tabular}

Table $2 b$. Descriptive statistics of daily returns - mid cap stocks

\begin{tabular}{lrrrrrr}
\hline & $\begin{array}{c}\text { Persistent } \\
\text { Systems }\end{array}$ & Firstsource & Cyient & Hexaware & $\begin{array}{c}\text { Sonata } \\
\text { Software }\end{array}$ & $\begin{array}{c}\text { Zenstar } \\
\text { Tech }\end{array}$ \\
\hline Mean & $-0.03 \%$ & $0.12 \%$ & $0.02 \%$ & $-0.02 \%$ & $0.13 \%$ & $0.13 \%$ \\
Std Dev & $2.38 \%$ & $2.87 \%$ & $2.21 \%$ & $2.76 \%$ & $3.03 \%$ & $2.66 \%$ \\
Sharpe & -0.0217 & 0.0316 & -0.0008 & -0.0149 & 0.0351 & 0.0394 \\
Skewness & -1.5976 & 0.3610 & 0.5866 & -1.0781 & 0.6683 & 0.5791 \\
Max. & $6.36 \%$ & $11.42 \%$ & $11.67 \%$ & $12.89 \%$ & $14.57 \%$ & $12.74 \%$ \\
Min. & $-16.64 \%$ & $-7.98 \%$ & $-6.70 \%$ & $-15.65 \%$ & $-10.90 \%$ & $-8.99 \%$ \\
\hline
\end{tabular}

Table 2c. Descriptive statistics of daily returns - small cap stocks

\begin{tabular}{lrrrr}
\hline & Eclerx & NIIT Tech & S/W Exp & Mastek \\
\hline Mean & $-0.10 \%$ & $0.23 \%$ & $-0.14 \%$ & $0.07 \%$ \\
Std Dev & $1.87 \%$ & $2.80 \%$ & $2.61 \%$ & $3.00 \%$ \\
Sharpe & -0.0677 & $\mathbf{0 . 0 7 2 1}$ & -0.0629 & 0.0162 \\
Skewness & 0.9943 & -0.0943 & 0.7791 & 0.6979 \\
Max. & $9.85 \%$ & $9.50 \%$ & $13.12 \%$ & $15.18 \%$ \\
& & & & - \\
Min. & $-5.17 \%$ & $-12.22 \%$ & $-6.87 \%$ & $10.32 \%$ \\
\hline
\end{tabular}

The performance of the sample IT sector stocks varied considerably, with mean daily returns ranging between $-0.14 \%$ and $0.23 \%$, and the volatility of daily returns ranging between $1.40 \%$ and $3.03 \%$. In terms of risk-adjusted excess returns (i.e. Sharpe ratio), several stocks outperformed the Nifty 50 index, which had a Sharpe ratio of 0.0626 , particularly among the large-cap IT stocks. The best-performing stock was TCS, with a Sharpe ratio of 0.0898. Some of the sample stock returns were considerably negatively skewed, particularly HCL Technologies, Mindtree, Persistent Systems, and Hexaware, while Eclerx was considerably 
positively skewed. Some very extreme negative daily returns and some very extreme positive daily returns were observed for several sample stocks: Mindtree (-18.36\%), Persistent Systems $(-16.64 \%)$, NIIT Technologies (-12.22\%), Mastek $(+15.18 \%$ and $-10.32 \%)$, Sonata Software $(+14.57 \%$ and $-10.90 \%)$, Hexaware $(+12.89 \%$ and $-15.65 \%)$, Nucleus Software Exports $(+13.12 \%)$, Zenstar Technologies $(+12.74 \%)$, Cyient $(+11.67 \%)$, Firstsource $(+11.42 \%)$, and L\&T Infotech $(+11.32 \%)$.

The results of the KPSS tests for stationarity of the returns of the sample stocks are presented in Table 3 below.

Table 3. Results of the KPSS test for stationarity

\begin{tabular}{|l|c|c|}
\hline KPSS & Stat & p-value \\
\hline Nifty 50 & 0.0542 & $>0.1000$ \\
\hline ICS & 0.1124 & $>0.1000$ \\
\hline Wiprosys Tech & 0.0956 & $>0.1000$ \\
\hline HCL Tech & 0.1405 & $\approx 0.0630$ \\
\hline Tech Mahindra & 0.1322 & $\approx 0.0780$ \\
\hline L \& T Tech & 0.1213 & $\approx 0.0970$ \\
\hline Mphasis & 0.1027 & $>0.1000$ \\
\hline MindTree & 0.0667 & $>0.1000$ \\
\hline Oracle Financials Services & 0.0222 & $>0.1000$ \\
\hline Software & & \\
\hline Persistent Systems & 0.1276 & $\approx 0.0860$ \\
\hline Firstsource & 0.1180 & $>0.1000$ \\
\hline Cyient & 0.0943 & $>0.1000$ \\
\hline Hexaware & 0.1175 & $>0.1000$ \\
\hline Sonata Software & 0.1245 & $\approx 0.0920$ \\
\hline Zenstar Tech & 0.0844 & $>0.1000$ \\
\hline Eclerx & 0.0590 & $>0.1000$ \\
\hline NIIT Tech & 0.1441 & $\approx 0.0570$ \\
\hline Nucleus Software Exports & 0.1100 & $>0.1000$ \\
\hline Mastek & 0.1144 & $>0.1000$ \\
\hline & 0.1322 & $\approx 0.0780$ \\
\hline & & \\
\hline
\end{tabular}

All of the sample stock daily returns and Nifty 50 daily returns were found to be stationary at $5 \%$ level of significance.

The results of the market model regressions are summarised in Table 4 below. 


\section{Macrothink}

Table 4. Results of market model regressions

\begin{tabular}{|l|c|c|c|c|}
\hline & alpha & beta & $\mathbf{R}^{\mathbf{2}}$ & p-value \\
\hline TCS & $0.17 \%$ & 0.2155 & $1.07 \%$ & 0.1062 \\
\hline Infosys Tech & $0.13 \%$ & 0.1857 & $0.97 \%$ & 0.1247 \\
\hline Wipro Tech & $0.07 \%$ & 0.0211 & $0.01 \%$ & 0.8537 \\
\hline HCL Tech & $0.08 \%$ & 0.0387 & $0.03 \%$ & 0.7889 \\
\hline Tech Mahindra & $0.17 \%$ & 0.2488 & $1.01 \%$ & 0.1168 \\
\hline L \& T Tech & $0.19 \%$ & 0.1620 & $0.26 \%$ & 0.4284 \\
\hline Mphasis & $0.13 \%$ & 0.1855 & $0.39 \%$ & 0.3316 \\
\hline MindTree & $0.19 \%$ & 0.3313 & $0.99 \%$ & 0.1212 \\
\hline $\begin{array}{l}\text { Oracle Financials Services } \\
\text { Software }\end{array}$ & $-0.02 \%$ & 0.1109 & $0.28 \%$ & 0.4073 \\
\hline Persistent Systems & $-0.04 \%$ & 0.3765 & $1.53 \%$ & 0.0529 \\
\hline Firstsource & $0.12 \%$ & -0.0919 & $0.06 \%$ & 0.6956 \\
\hline Cyient & $0.03 \%$ & -0.0995 & $0.12 \%$ & 0.5827 \\
\hline Hexaware & $-0.01 \%$ & -0.0783 & $0.05 \%$ & 0.7292 \\
\hline Sonata Software & $0.13 \%$ & 0.2215 & $0.33 \%$ & 0.3721 \\
\hline Zenstar Tech & $0.12 \%$ & 0.3525 & $1.08 \%$ & 0.1044 \\
\hline Eclerx & $-0.10 \%$ & -0.0331 & $0.02 \%$ & 0.8290 \\
\hline NIIT Tech & $0.24 \%$ & -0.3358 & $0.88 \%$ & 0.1428 \\
\hline Nucleus Software Exports & $-0.14 \%$ & 0.1263 & $0.14 \%$ & 0.5552 \\
\hline Mastek & $0.07 \%$ & 0.2339 & $0.37 \%$ & 0.3415 \\
\hline
\end{tabular}

It was found that none of the market model regressions were statistically significant at $5 \%$ level of significance, with the highest $\mathrm{R}^{2}$ at $1.53 \%$. Further, the beta estimates were found to be relatively low and statistically insignificant. Thus, the market model was not adequate in explaining stock returns for IT sector stocks.

The results of the vector autoregressive model regressions are summarised in Table 5 below. 


\section{Macrothink}

Asian Journal of Finance \& Accounting ISSN 1946-052X 2021, Vol. 13, No. 1

Table 5. Results of vector autoregressive model regressions

\begin{tabular}{|l|c|c|c|c|c|c|}
\hline & alpha & phi $_{1}$ & beta $_{\mathbf{M}}$ & beta $_{\mathbf{M}(-\mathrm{i})}$ & $\mathbf{R}^{\mathbf{2}}$ & $\mathbf{p}$-value \\
\hline TCS & $0.16 \%$ & -0.0540 & 0.2066 & $0.4363^{* *}$ & $5.52 \%$ & 0.0034 \\
\hline Infosys Tech & $0.12 \%$ & -0.0400 & 0.1664 & $0.6353^{* *}$ & $8.83 \%$ & 0.0001 \\
\hline Wipro Tech & $0.06 \%$ & 0.0414 & 0.0186 & $0.3111^{* *}$ & $3.24 \%$ & 0.0328 \\
\hline HCL Tech & $0.06 \%$ & -0.0482 & 0.0165 & $0.5252^{* *}$ & $5.62 \%$ & 0.0030 \\
\hline Tech Mahindra & $0.16 \%$ & -0.0331 & 0.2163 & $0.5852^{* *}$ & $6.44 \%$ & 0.0002 \\
\hline L \& T Tech & $0.16 \%$ & -0.0023 & 0.1387 & $0.9145^{* *}$ & $8.47 \%$ & 0.0001 \\
\hline Mphasis & $0.12 \%$ & -0.0201 & 0.1711 & $0.3856^{* *}$ & $2.06 \%$ & 0.0448 \\
\hline MindTree & $0.17 \%$ & 0.0073 & 0.3050 & $0.8405^{* *}$ & $7.35 \%$ & 0.0004 \\
\hline Oracle Financials Services & & & & & & \\
Software & $-0.04 \%$ & $-0.1288^{*}$ & 0.0898 & $0.5304 * *$ & $7.96 \%$ & 0.0002 \\
\hline Persistent Systems & $-0.06 \%$ & -0.0180 & $0.3541 *$ & $0.6599 * *$ & $6.15 \%$ & 0.0016 \\
\hline Firstsource & $0.08 \%$ & 0.0718 & -0.1252 & $1.1600^{* *}$ & $10.47 \%$ & 0.0000 \\
\hline Cyient & $0.01 \%$ & -0.0077 & -0.1271 & $0.6051^{* *}$ & $4.73 \%$ & 0.0086 \\
\hline Hexaware & $-0.03 \%$ & -0.0371 & -0.0913 & $0.7862^{* *}$ & $5.16 \%$ & 0.0052 \\
\hline Sonata Software & $0.06 \%$ & $0.1228 *$ & 0.1521 & $1.3842^{* *}$ & $15.07 \%$ & 0.0000 \\
\hline Zenstar Tech & $0.08 \%$ & $0.1038^{*}$ & 0.3265 & $0.7718^{* *}$ & $7.82 \%$ & 0.0002 \\
\hline Eclerx & $-0.12 \%$ & -0.0072 & -0.0596 & $0.5064^{* *}$ & $4.52 \%$ & 0.0111 \\
\hline NIIT Tech & $0.19 \%$ & 0.0593 & -0.3556 & $1.1867 * *$ & $11.80 \%$ & 0.0000 \\
\hline Nucleus Software Exports & $-0.17 \%$ & 0.0708 & 0.0829 & $1.1300^{* *}$ & $12.26 \%$ & 0.0000 \\
\hline Mastek & $0.05 \%$ & -0.0013 & 0.1891 & $1.1989 * *$ & $10.08 \%$ & 0.0000 \\
\hline
\end{tabular}

The optimal lag structure minimising the AIC was found to be $\mathrm{p}=\mathrm{q}=1$ for all of the vector autoregressive models. It was found that all of the vector autoregressive model regressions were statistically significant at $5 \%$ level of significance, with $\mathrm{R}^{2}$ in the range of $2.06 \%$ to $15.07 \%$. Further, the beta estimates for one-day lagged Nifty 50 returns were all found to be statistically significant at $1 \%$ level of significance. Thus, the vector autoregressive model was adequate in explaining stock returns for IT sector stocks.

The results of the nested F-tests are summarised in Table 6 below. 
Table 6. Results of nested F-tests

\begin{tabular}{|l|r|r|}
\hline & \multicolumn{1}{|c|}{ F Stat } & p-value \\
\hline TCS & 5.6520 & 0.0040 \\
\hline Infosys Tech & 10.3455 & 0.0000 \\
\hline Wipro Tech & 4.0058 & 0.0194 \\
\hline HCL Tech & 7.1074 & 0.0010 \\
\hline Tech Mahindra & 6.9645 & 0.0011 \\
\hline L \& T Tech & 10.7637 & 0.0000 \\
\hline Mphasis & 3.1396 & 0.0451 \\
\hline MindTree & 8.2375 & 0.0003 \\
\hline $\begin{array}{l}\text { Oracle Financials Services } \\
\text { Software }\end{array}$ & 10.0130 & 0.0001 \\
\hline Persistent Systems & 5.9073 & 0.0031 \\
\hline Firstsource & 13.9529 & 0.0000 \\
\hline Cyient & 5.8067 & 0.0034 \\
\hline Hexaware & 6.4656 & 0.0018 \\
\hline Sonata Software & 20.8266 & 0.0000 \\
\hline Zenstar Tech & 8.7741 & 0.0002 \\
\hline Eclerx & 5.6556 & 0.0040 \\
\hline NIIT Tech & 14.8571 & 0.0000 \\
\hline Nucleus Software Exports & 16.5762 & 0.0000 \\
\hline Mastek & 12.9582 & 0.0000 \\
\hline
\end{tabular}

It was found that the vector autoregressive model was significant over the market model for all sample stocks at $5 \%$ level of significance.

\section{Discussion}

The results of the study suggest that the vector autoregressive model is a better model of stock returns than the market model. Specifically, as the one-day lagged Nifty 50 returns were found to be statistically significant at $1 \%$ level of significance, IT sector stocks seem to react more to market movements from the previous day than on the day itself. This could be due to the relative isolation of IT stocks from domestic economic shocks, as their customer base is primarily the American and European markets.

The implication for asset pricing modelling is that systematic risk may be further decomposed into a component corresponding to sensitivity to market movements on the day and a component corresponding to sensitivity to market movements on the previous day. The asset pricing model would be extended to include market risk premia for both of these components of systemic risk. This would need to be formalised theoretically and tested empirically in other sectors. 


\section{$\Lambda$ Macrothink}

Asian Journal of Finance \& Accounting ISSN 1946-052X 2021, Vol. 13, No. 1

There are some limitations inherent in the study. The sample size for the study was relatively small, only nineteen stocks in the IT sector, and the research period was very short, only one year. Thus, the results of the study may not be generalisable. Additionally, the data of the sample stocks may contain many outliers, as there were several stocks with very extreme positive and negative daily returns, which may have affected the significance of the market model regressions. There is also the possibility of multicollinearity, as there may be significant autocorrelation in index returns, and heteroskedasticity. The latter may require a GARCH model approach. Also, the highest $\mathrm{R}^{2}$ attained using the vector autoregressive model was a little above $15 \%$, suggesting that there is scope to include other factors to improve the explanatory power. In particular, for the IT sector, exchange rates would be expected to play a major role. Further, other indices may be more appropriate than the Nifty 50 index; for example the NiftyIT index or even the S\&P 500 index. Other macroeconomic variables may also play an important role. These should be investigated in future studies.

\section{References}

Brown, S.J., \& Warner, J.B. (1980). Measuring Security Price Performance. Journal of Financial Economics, 8, 205-258. https://doi.org/10.1016/0304-405X(80)90002-1

Carhart, M. (1997). On Persistence in Mutual Fund Performance. Journal of Finance, 52(1), 57-82. https://doi.org/10.1111/j.1540-6261.1997.tb03808.x

Chan, K. (1993). Imperfect information and cross-autocorrelation among stock prices. Journal of Finance, 48(4), 1211-1230. https://doi.org/10.1111/j.1540-6261.1993.tb04752.x

Coutts, J.A., Roberts, J., \& Mills, T.C. (1997). Parameter stability in the market model: tests and time varying parameter estimation with UK data. Journal of the Royal Statistical Society: Series D (The Statistician), 46(1), 57-70. https://doi.org/10.1111/1467-9884.00059

Dash, M. (2014). Granger Causality and the Capital Asset Pricing Model. Journal of Applied Management and Investments, 3(2), 68-73.

Dash, M. (2017). A Study of Granger Causality in the CAPM. i-manager's Journal on Management, 11(4), 61-68. https://doi.org/10.26634/jmgt.11.4.13452

Fama, E.F., \& French, K.R. (1996). Multifactor Explanations of Asset Pricing Anomalies. Journal of Finance, 51(1), 55-84. https://doi.org/10.1111/j.1540-6261.1996.tb05202.x

Fama, E.F., \& MacBeth, J. D. (1973). Risk, Return, and Equilibrium: Empirical Tests. Journal of Political Economy, 81(3), 607-636. https://doi.org/10.1086/260061

Gibbons, M. R. (1988). Multivariate tests of financial models: a new approach. Journal of Financial Economics, 10(1), 3-27. https://doi.org/10.1016/0304-405X(82)90028-9

Jegadeesh, N., \& Titman, S. (1993). Returns on buying winners and selling losers: implications for market efficiency. Journal of Finance, 48(1), 64-91. https://doi.org/10.1111/j.15406261.1993.tb04702.x 


\section{Macrothink}

Asian Journal of Finance \& Accounting ISSN 1946-052X 2021, Vol. 13, No. 1

McDonald, B., \& Lee, C.-F. (1988). An analysis of nonlinearities, heteroskedasticity and functional form in the market model. Journal of Business and Economic Statistics, 6, 505-509. https://doi.org/10.1080/07350015.1988.10509699

Mills, T.C. (1995). The Econometrics of the 'Market Model': Cointegration, Error Correction and Exogeneity. International Journal of Finance Economics, 1(4), 275-286.

Ross, S. A. (1976). The arbitrage theory of capital asset pricing. Journal of Economic Theory, 13(3), 341-360. https://doi.org/10.1016/0022-0531(76)90046-6

Sharpe, W. F. (1963). A Simplified Model for Portfolio Analysis. Management Science, 9(2), 277-293. https://doi.org/10.1287/mnsc.9.2.277

Soufian, N. (2001). Empirical Content of Capital Asset Pricing Model (CAPM) and Arbitrage Pricing Theory (APT) Across Time. Manchester Metropolitan University Business School Working Paper Series, WPSO10. 